\title{
Discursos sobre a sexualidade contemporânea no Brasil
}

\author{
Discourse on nowadays sexuality in Brazil
}

\author{
Claudemir Sousa ${ }^{1}$
}

Resumo: Neste artigo, analisamos quatro enunciados brasileiros que circulam em diferentes materialidades discursivas e que têm como objeto a sexualidade. O objetivo é discutir como o sexo é posto em relação com os domínios da saúde, da religião, da política e da família, fazendo derivar uma série de temas. Para tanto, ancoramo-nos nas discussões de Foucault (1999; 2002; 2008; 2019) acerca do discurso como prática e da sexualidade como um dispositivo historicamente construído, para analisar as materialidades enunciativas em sua densidade histórica, pondo-as em um campo associado, ou seja, em uma série de enunciados relacionados. Conclui-se que os dizeres sobre a sexualidade no Brasil contemporâneo são marcados por disputas em torno dos conceitos de família, do uso dos corpos dos sujeitos e do gozo de direitos civis, que vagam pelos campos da saúde, da religião, da intimidade familiar e da política.

Palavras-chave: Discurso. Política. Sexualidade. Saúde. Família.

Abstract: In this article, we analyze four Brazilian statements that circulated in deferent discursive materialities and that concern to the sexuality. The main objective is to discuss on how sex is related to the domains of health, religion, politics and family, making derivate a series of themes. Thus, we anchor our discussion on Foucault's $(1999 ; 2002 ; 2008 ; 2019)$ theory about discourse as a practice and the sexuality as a historically made device, to analyze the discursive materialities in its historical density, punting them in an associated field, it is, in a series of statements. We concluded that the sayings about sexuality in Brazil nowadays are characterized by struggles involving the conceptions of family, the use of peoples' body and the enjoying of civil rights, crossing the fields of health, religion, family intimacy and politics.

Keywords: Discourse. Politics. Sexuality. Health. Family.

\footnotetext{
${ }^{1}$ Instituto Federal de Educação, Ciência e Tecnologia do Maranhão, Pedreiras, MA, Brasil. Endereço eletrônico: claudemir201089@hotmail.com.
} 


\section{Introdução}

São diversas essas questões. Desde a grave epidemia das drogas, que dilacera os laços e a harmonia do ambiente familiar, à violência doméstica, à gravidez na adolescência, até mesmo à desconstrução do conceito de família, aspecto que aflige as famílias e repercute na dinâmica psicossocial do indivíduo (PL $\mathrm{n}^{\circ} 6.583 / 2013$, p. 6$)$.

Não tenho nada contra o cuidado do Ministério da Saúde com o povo brasileiro, mas acho que essa vacina é desnecessária. A melhor forma de prevenir Doenças Sexualmente Transmissíveis (DSTs) é a fidelidade no casamento (RAQUEL DINIZ JANTORNO, 2014, online).

Nós tratamos a vida toda com a religiosidade pra que nossos filhos possam encontrar, realmente, um bom caminho familiar. Então, Luciana, eu lamento muito. Que façam bom proveito se querem fazer e continuar como estão, mas eu, presidente da República, não vou estimular (LEVY FIDELIX, 2014, online).

Estamos lançando hoje a campanha à prevenção da gravidez precoce. O que estou falando é da prevenção ao sexo precoce, vamos continuar falando disso, isso não se encerra em uma campanha, em um dia, é uma conversa por muito tempo e por gerações (DAMARES ALVES, 2020, online).

Família, saúde, sexo e gravidez na adolescência, casamento, fidelidade e religião são os temas que emergem nos enunciados precedentes, os quais compõem o quadro contemporâneo de discursos sobre a sexualidade no Brasil. Esses enunciados entrelaçam os domínios discursivos (FOUCAULT, 2008) da saúde, da religião, da vida familiar e privada, convergindo para o âmbito político. Nesses dizeres, formulados por sujeitos cristãos, a sexualidade clama ao Estado por formas de regulamentação: propõe-se uma definição do conceito de família, uma regulação das práticas corporais dos sujeitos, a restrição do sexo à idade adulta e ao casamento, e propugna-se a fidelidade conjugal como via para uma vida saudável e a religiosidade como caminho para a harmonia social.

Embora esses sujeitos enunciem que respeitam as opções de vida que estejam fora dos ditames que eles apregoam, esses enunciados revelam a existência, no Brasil, de lutas em torno das práticas corporais e sexuais e da vida familiar, que põem em lados opostos os sujeitos que se declaram de direita, conservadores e adeptos das religiões judaico-cristãs, de um lado, e os sujeitos LGBTQIA $+^{2}$, os militantes de esquerda, os adeptos de outras formas de religiões e os defensores da ciência como estratégia biopolítica (FOUCAULT, 1999) de regulação da vida e saúde dos indivíduos nas sociedades contemporâneas, por outro lado.

\footnotetext{
${ }^{2}$ Sigla para Lésbicas, Gays, Bissexuais, Travestis, Transexuais, Transgêneros, Queers, Intersexuais e Assexuais.
} 
Esse embate em torno da sexualidade não é novo. A história da nossa sexualidade é marcada por diferentes instituições (igreja, tribunal, clínica) que a regulam, procedimentos em torno dela (repressão, condenação, cura, terapia, normalização) e autorização de diferentes sujeitos como legítimos para dela tratar (padre, juiz, médico, psicólogo, psiquiatra). Diante disso, questiona-se: quais discursos formulados no Brasil no âmbito do debate político atual compõem nosso dispositivo de sexualidade? Quais conceitos, objetos e escolhas temáticas emergem nesses discursos? Que posições são suscitadas pelos sujeitos neles implicados? Tais questões nos auxiliarão na consecução desse trabalho, que objetiva discutir como o sexo é relacionado com os domínios da saúde, religião, política e família.

Para realizar essa discussão, analisaremos quatro enunciados produzidos no Brasil, os quais circulam em diferentes materialidades e têm como objeto a sexualidade: o Projeto de Lei (PL) $n^{\circ}$ 6.583/2013, de autoria do Deputado Federal Anderson Ferreira, do Partido Liberal (PL); falas de um vídeo do debate entre os então candidatos à presidência Luciana Genro, do Partido Socialismo e Liberdade (PSOL), e Levy Fidélix, do Partido Renovador Trabalhista Brasileiro (PRTB), de 2014; uma reportagem do Jornal Estado do Espírito Santo, com falas de evangélicos sobre a vacina contra o Vírus Papiloma Humano (HPV, na sigla em inglês), de 2014; e falas de um vídeo de lançamento da campanha pela abstinência sexual de jovens no Brasil, pela Ministra Damares Alves, do Ministério da Mulher, da Família e dos Direitos Humanos, de 2020. Tais enunciados foram escolhidos dada a sua repercussão acerca dessa discussão.

Nossa análise se ancora nos pressupostos de Foucault $(1999 ; 2002 ; 2008 ; 2019)$ acerca do discurso, como prática histórica que se reparte em conceitos, objetos, modalidades enunciativas e escolhas teóricas, e sobre a sexualidade, como um dispositivo histórico que engendra nossa atual concepção de sujeito da sexualidade. Essa análise enunciativa (FOUCAULT, 2008) subsumi a densidade histórica e o campo associado do qual os enunciados fazem parte. Assim, recorreremos a outros enunciados, com base nos princípios foucaultianos da dispersão, da regularidade e do domínio de memória, nos quais reside essa historicidade.

Essa discussão está organizada da seguinte forma: adiante, discutiremos as teorizações de Foucault (1999; 2002; 2008; 2019) acerca do discurso e da sexualidade. Em seguida, realizaremos as análises das quatro materialidades enunciativas já especificadas, relacionandoas a outras com as quais mantêm regularidades. Por fim, apresentamos as considerações finais. 


\section{Foucault e o discurso: dispositivo de sexualidade e regulação dos prazeres}

A existência de uma vasta produção bibliográfica sobre a história da disciplina Análise do Discurso na área de Letras e Linguística torna dispensável fazermos esse percurso ${ }^{3}$. Entretanto, não podemos deixar de dizer que essa disciplina é formada por múltiplas abordagens teóricas e aquela a que nos filiamos é decorrente da teoria de Michel Foucault, autor que pensa o discurso como prática histórica e localizada no tempo/espaço (FOUCAULT, 2008) e como jogo polêmico e estratégico (idem, 2002), visto que dá a ver lutas de poder, em um jogo de ação e reação. O discurso como prática implica formulação de conceitos, objetos, temas e posições possíveis aos sujeitos em torno de certos fenômenos, do qual tratamos aqui da sexualidade.

Foucault investigou a sexualidade em um conjunto de quatro obras, das quais recorremos aos volumes 1 e 4. Trata-se de uma investigação arqueológica, visto que esse autor mostra como, historicamente, saberes de variadas ordens, como os da moral filosófica pagã, da moral religiosa cristã, saberes médicos, etc., bem como as instituições em torno desses saberes, constituem conhecimentos e práticas sobre a sexualidade e conduzem ao desenvolvimento de uma ciência sexual. É uma investigação genealógica, na medida em que ele também mostra como o corpo é o ponto central dessa história, alvo de tecnologias de coerção, disciplinamentos e regulamentações, que normalizam condutas, e de tecnologias do eu, que produzem o governo de si, formam uma verdade sobre si, como o autoexame, o exame da consciência e a confissão.

No volume 1 dessa coletânea, Foucault (1999) desenvolveu o conceito de dispositivo de sexualidade, que consiste em um conjunto heterogêneo de elementos, tais como: discursos, instituições, decisões regulamentares, decretos, leis, etc., na forma como esses elementos se relacionam entre si e também na tentativa de responder a uma determinada urgência histórica.

Esse conceito não coincide com o de sexo, que, por um lado, é compreendido como ato realizado entre corpos (ato sexual) e, por outro lado, Butler (2000) o concebe como uma categoria que foi ligada à diferença material dos corpos, mas que também é marcada e formada por práticas discursivas. O sexo é um ideal regulatório, uma norma que possui poder de produzir os corpos que controla: demarca diferenças e as faz circular. A sexualidade é um dispositivo histórico "em que a estimulação dos corpos, a intensificação dos prazeres, a incitação ao discurso, a formação dos conhecimentos, o reforço dos controles e das resistências, encadeiamse uns aos outros, segundo algumas grandes estratégias de saber e de poder" (FOUCAULT, 1999, p. 100). Ela está ligada a dispositivos recentes de poder. Sua expansão foi sustentada em

\footnotetext{
${ }^{3}$ Por isso, indica-se a leitura de Gregolin (2004), Maldidier (1997) e Orlandi (2002) para mais detalhe sobre o percurso de construção e reconfiguração da Análise do Discurso na França e no Brasil.
} 
função da intensificação do corpo, sua valorização como objeto de saber e elemento nas relações de poder. O sexo, por seu turno, é uma construção ideal, um processo pelo qual as normas materializam o sexo do corpo pela nomeação, fazendo-o entrar para uma dada ordem.

Já na obra "História da sexualidade 4: as confissões da carne", Foucault (2019) expõe a problematização da carne nos primeiros séculos do Cristianismo, abordando a experiência da carne e seu papel na hermenêutica e decifração purificadora do desejo. Esse estudo se vale de uma larga fonte, que trata dos rituais de penitência e dos princípios da direção monástica. Para este artigo, iremos nos voltar, sobretudo, às discussões sobre a procriação, a fidelidade, o casamento e a temperança, para analisarmos enunciados brasileiros atuais que tratam da sexualidade e discutir as remanências (FOUCAULT, 2008) discursivas em torno desse objeto.

Dessa maneira, Foucault (2019) afirma que os atos que proporcionam o prazer (afrodisia) foram regulados em torno do casamento em formulações feitas por filósofos, não por cristãos, e que depois foram adotadas pelos Padres do século II. Os princípios não estão nos textos bíblicos, mas sim na filosofia helenística. Os cristãos põem-nos em prática em formas semelhantes às dos filósofos sobre casamento, procriação e afrodisia.

Nas discussões que esse autor faz acerca de temas que emergem no pensamento de filósofos da Antiguidade e suas regularidades com o pensamento dos teóricos cristãos, são evocados os temas do celibato, do casamento, da procriação, da fidelidade no casamento e do desprezo aos prazeres do sexo, visto que sua finalidade é a procriação.

A exposição desses temas pelos pensadores cristãos tinha a finalidade de salvar almas, unindo-as a Deus pela condução à vida eterna. Esse governo das almas passa pelo corpo, pois estabelece regulações dos usos do prazer. É nesse sentido que Clemente de Alexandria, citado por Foucault (2019), dá uma significação cristã aos princípios filosóficos e se reporta também a naturalistas, médicos e às Sagradas Escrituras para levantar temas prescritivos sobre o casamento como busca da procriação, a busca do prazer como contrária à razão e as formas indecentes e vergonhosas da relação sexual.

A ideia de que existem formas naturais de relações sexuais se baseia em três referências: dos naturalistas e médicos, segundo os quais a natureza fundamenta esses princípios e manifesta sua racionalidade; de filósofos, principalmente Platão, segundo os quais a razão humana pode reconhecer e justificar tais princípios moralistas; e nas sagradas escrituras, segundo as quais Deus deu mandamentos aos homens e quem lhes obedecer se unirá a ele na vontade.

Foi sob essa tripla determinação (natureza, razão filosófica e palavra de Deus) que Clemente de Alexandria formulou regras para as relações conjugais em que a procriação se estabeleceu como a finalidade do casamento, condenando as relações contranatura, o sexo 
durante a gravidez, as relações infecundas, o adultério e o aborto, que constituem os "princípios da medida e da conveniência" (FOUCAULT, 2019, p. 30) para as relações matrimoniais.

Com base nessa tríplice referência, estabeleceu-se uma economia das relações sexuais, na qual o corpo é regulado em seus movimentos naturais, no controle dos desejos e dos excessos e na condenação das relações contranatura, propugnando que se utilize do sexo com reserva no casamento, pois seu excesso acarreta doenças. $\mathrm{O}$ casamento seria, então, regido não pelo prazer e pela volúpia, mas pelo logos. A procriação, como sua finalidade, não se confunde com o alvo e objetivo da relação sexual. Esse último é a existência de progenitura em si. O seu alvo é mais utilitário: consiste em que se tenha sustento na velhice. O fim que Clemente elenca não é utilitário. É uma obediência aos princípios de Deus (crescei-vos e multiplicai-vos) e uma forma de se assemelhar ao Criador com a procriação, na medida em que segue a lei que a prescreve em conformidade com a natureza, porque esta obedece a lei de Deus.

Para elaborar esses conceitos de "natura" e "contranatura", Foucault (2019) expõe o exemplo da hiena e da lebre, discutido por Clemente de Alexandria, segundo o qual a primeira tinha dois sexos e os desempenhava alternadamente a cada ano e a segunda adquiria todo ano um ânus a mais para fazer um mau uso. Clemente trata do hermafroditismo da hiena para observar uma lição moral acerca da natureza e da contranatura. Para ele, essa mudança de sexo não ocorria, por ser contrária à natureza, que fixa o que um animal é e não se pode modificar. Estendendo essa reflexão para o sexo, Foucault (2019, p. 43) relata que, nesse pensamento filosófico, "um indivíduo não pode nem mudar de sexo, nem ter dois, nem também ser de um terceiro que seria intermédio entre o masculino e o feminino: tais coisas são quimeras que os homens imaginam, mas às quais a natureza se recusa".

Nesse sistema de pensamento, o homem e a mulher são diferentes por natureza e devem assim permanecer. Qualquer forma de metamorfose corporal é compreendida como contranatura. Clemente via na crença dos dois sexos da hiena um efeito e um instrumento de uma falha moral, já que as hienas teriam o corpo estranhamente disposto por causa de um vício de natureza, próprios da espécie, semelhante à falha moral própria dos homens: a lascívia.

Esse discurso possui regularidades (FOUCAULT, 2008) com a fala de Levy Fidelix acerca das práticas homossexuais, ao afirmar que órgão excretor não procria, pois aponta para a finalidade do sexo na discursividade cristã e condena os excessos, por constituírem, conforme aponta Foucault (2019), a partir de Clemente, uma contranatura porque desvia da finalidade de procriação. Esse ato sexual é considerado contrário à natureza, inútil e estéril, assim como o é o exemplo da lebre, do exagero da fecundação. 
Assim, desde a antiguidade os filósofos estabelecem que o uso da afrodisia é regulado pela natureza do homem como ser racional e social. A própria natureza mostra essa relação do ato sexual com a procriação e condena quem escapa a essa existência. Este princípio produz interdição a todo o ato feito fora dos órgãos da fecundação (princípio da hiena) ou quando a fecundação estiver em curso (princípio da lebre).

Também são interditados pelos filósofos a fornicação, o adultério e a corrupção de crianças. Para regular tais domínios, estabelece-se o princípio da temperança, segundo o qual é necessário dominar os prazeres, satisfazer seu apetite com moderação e reserva depois de se tornar senhor deles. Esses atos devem ser feitos com reserva: nas uniões tidas como legítimas, para sua finalidade e com decência. O domínio da razão sobre os apetites do corpo é regido pela natureza e tem como suas formas a monogamia, a abstinência das relações sexuais na menstruação, a interdição do sexo na gravidez e o uso moderado dos prazeres ou sua abstinência. $\mathrm{O}$ código da temperança, estabelecido em torno dos desejos sexuais, impõe um controle da razão aos impulsos do corpo e se aplica ao casamento temperante. A temperança faz o corpo ser/continuar sendo o templo de Deus e seus membros os membros de Cristo.

Nas discussões de Clemente de Alexandria apresentadas por Foucault (2019), o sexo, que tem por finalidade a procriação no casamento, precisa de momento oportuno. Assim, os atos sexuais são definidos em função dos seus fins racionais e das ocasiões que lhes são legítimas. Clemente deu uma significação religiosa a esse conjunto de prescrições éticas do casamento e de uma economia das relações sexuais, o que significa que não foi o Cristianismo por si só que impôs esse conjunto de práticas, notações e regras a que se chama de "a" moral sexual cristã, mas sim moralistas pagãos e cristãos, como Santo Agostinho, que terá maior papel na cristalização da moral cristão.

Segundo Foucault (2019), a proibição do incesto é uma interdição que se desenvolveu na moral das relações sexuais durante a Alta Idade Média. Outras transformações se operaram no Cristianismo, fazendo-se desenvolver práticas como a ascese monástica, a penitência e a confissão, questões que não iremos pormenorizar. Quanto à abstinência sexual e virgindade feminina, esse autor remonta ao século IV para mostrar como textos dessa época concediam importância a esse estado, que não é uma novidade, visto que sua valorização é atestada em épocas anteriores, incluindo no texto sagrando, que orienta a vida sexual de pessoas há milênios.

A virgindade ou continência definitiva era uma prática difundida entre os cristãos no século II, mas sem novidades ou especificidades, pois as interdições dos textos dos Padres Apostólicos e dos Apologetas são as mesmas proibições presentes na moral pagã: "adultério, fornicação, corrupção de crianças" (FOUCAULT, 2019, p. 167). Assim, nos seus primeiros 
séculos, o Cristianismo veicula o mesmo sistema de moral sexual da cultura antiga precedente ou concomitante. Tais recomendações reaparecem em enunciados brasileiros atuais, que analisaremos, mas não consistem em uma simples extensão de recomendações filosóficas, já que diferem pela fixação de outros efeitos ao princípio de continência: outras promessas, outra extensão, outros instrumentos.

No século III, existiam círculos de mulheres virgens, que se dedicavam à vida religiosa e evitavam o casamento ou viúvas, que recusavam um segundo casamento e havia também as meninas impelidas à virgindade pela família. Até os séculos V e VI o pensamento cristão vai elaborar a virgindade como ponto maior de reflexão e lugar da transformação. As discussões sobre esse tema nesses dois séculos são feitas por Foucault (2019) a partir dos textos de Tertuliano, nos quais busca os principais temas relacionados à virgindade e à continência e a maneira como argumentos das escrituras e da natureza são mobilizados, bem como suas regularidades com as discussões de Cassiano, Basílio de Ancira, Gregório de Nissa, Metódio de Olimpo e São Cipriano.

Foucault (2019) diferencia virgindade (renúncia à relação sexual, não necessariamente total), castidade (um estado em que a relação sexual é feita de forma temperante) e celibato (voto de renúncia total ao ato sexual). A virgindade e a prática pagã da continência possuem relação, na medida em que os autores cristãos do século IV “contraíram empréstimos relativamente importantes de regras de vida inspiradas pela moral dos filósofos. E chegaram até mesmo a transpor directamente certos elementos seus" (FOUCAULT, 2019, p. 198).

Nas exegeses de autores cristãos, a experiência sexual foi pensada com relação à queda de Adão e Eva do paraíso. A literatura cristã também versa sobre o casamento. As primeiras dessas formulações apresentam uma arte da vida matrimonial que está, segundo Foucault (2019), próxima à moral antiga. É no fim do século IV que se desenvolvem reflexões e textos para guiar os cristãos casados na vida conjugal.

Assim, o casamento se torna um domínio de análise e de exercício na esteira do desenvolvimento da vida monástica e da prática de direção dos indivíduos, que fazem com que valores, preocupações e práticas elaboradas para a vida de ascese se movimentem para a vida do mundo. Além disso, a relação entre o Cristianismo e o Império puseram a Igreja Cristã em uma posição de gestão da vida social e individual.

Essa pastoral da vida quotidiana está em relação com a moral da filosofia antiga e modifica uma série de práticas elaboradas para a vida monástica para poder intervir na sociedade civil, penetrando na vida íntima dos indivíduos. O Cristianismo se constitui como religião de Estado, com as instituições eclesiásticas. Mesmo não se estabelecendo como regra 
de vida praticada por todos, a moral cristã se apresenta como universal e o casamento constitui uma das peças essências da ética cristã. Na esteira do desenvolvimento da administração imperial, a família ganha um papel importante, como elemento base da sociedade e ponto de articulação entre a conduta moral individual e as leis universais.

A partir do século $\mathrm{V}$, as reflexões sobre o casamento põem-no em aproximação com a relação entre Cristo e a Igreja, dão-lhe um valor positivo, aproximam-no da virgindade, e distinguem-no de uma incapacidade de abstinência. Entre os principais temas encontrados nessas reflexões, Foucault (2019) ressalta os seguintes princípios: desigualdade natural entre homem (comandante) e mulher (submissa); dever do esposo de ensinar valores à sua mulher; permanência do laço de matrimônio e reciprocidade, só desfeito em caso de adultério ou após a morte; laço afetivo como meta e condição permanente do bom casamento.

Ao analisar os textos de São João Crisóstomos, Foucault (2019) mostra que esse autor, diferente de Clemente de Alexandria e dos moralistas da Antiguidade, não via no casamento a finalidade da procriação, mas sim para que o homem vivesse na castidade e evitasse a fornicação e para que a mulher se contentasse com um só homem, elaborando uma lei da fidelidade, uma economia do desejo, uma solução para a concupiscência, o que o aproxima da virgindade, diferenciando-se pelo fato de as regras do casamento serem obrigações jurídicas, ao passo que as da virgindade são conselhos.

Esse dever entre esposos também se assemelha a uma dívida, consistindo em um tema jurídico-econômico da propriedade do corpo. Mas será apenas na Idade Média que a instituição jurídica fará aparecer os esposos como sujeitos de direito, a partir do momento em que o casamento se desliga da finalidade de procriação. Elabora-se uma teoria dos fins e dos bens do casamento, segundo a qual constituem bens do casamento a progenitura, a fé que une os cônjuges e o sacramento que os marca de modo indelével. Já o fim por si mesmo são a sabedoria e a saúde (beber, comer, dormir). Esses bens são reformulados por Santo Agostinho, fazendo com que a progenitura perca espaço para a fidelidade e para o sacramento. Assim, um casamento não se desfaz pela inexistência de progenitura, que constitui uma maneira de produzir ou desenvolver a societas.

Dessa maneira, as discussões de Foucault (2019) nos mostram que a sexualidade é uma experiência história, elaborada por uma série de enunciados, que regulam o ato sexual, formulam princípios para o casamento e visam atender interesses históricos. Com o Cristianismo, na Idade Média, "o sexo no casamento passa então a ser objecto de jurisdição e de veridicção" (FOUCAULT, 2019, p. 381), desenvolvendo-se diversas formas de se falar sobre ele, entre as quais os enunciados que analisaremos, que integra um dispositivo de sexualidade. 
Incitação ao discurso e repressão dos prazeres: os dizeres sobre a sexualidade, a saúde e a família nos discursos de políticos e religiosos brasileiros na atualidade

A concepção que adotamos aqui acerca da sexualidade na contemporaneidade é a de que, na esteira de Foucault (1999), não existe apenas repressão, mas incitação a falar sobre ela e um controle sobre as práticas sexuais, nomeadas de "sexo", por um mecanismo de poder que possui uma eficácia produtiva: produz saberes e sujeitos, está inscrito em relações de podersaber e é efeito dessas relações, que se entrecruzam na construção da nossa sexualidade.

Nesse sentido, o primeiro enunciado que analisamos é o PL nº 6.583/2013, do Deputado Federal Anderson Ferreira, do PL de Pernambuco (PE), que dispõe sobre o Estatuto da Família e dá outras providências. Esse Projeto foi apresentado no dia 16 de outubro de 2013 e ainda tramita no Congresso Nacional, devido às divergências entre os deputados sobre a definição de família apresentada no seu artigo $2^{\circ}$, como segue: "para os fins desta Lei, define-se entidade familiar como o núcleo social formado a partir da união entre um homem e uma mulher, por meio de casamento ou união estável, ou ainda por comunidade formada por qualquer dos pais e seus descendentes" (PL nº 6.583/2013, p. 1, grifos no original).

Nessa definição, o domínio discursivo com o qual o conceito de casamento apresenta regularidades (FOUCAULT, 2008) são as sagradas escrituras, que condenam relações entre pessoas do mesmo sexo. O sujeito que elaborou esse conceito de família faz penetrar na esfera civil e política os índices da religiosidade, contradizendo o caráter laico do estado brasileiro.

O relator desse PL foi o Deputado Diego Garcia, do Partido Humanista da Solidariedade (PHS), do Paraná (PR). Houve emendas a ele, sugeridas pelos Deputados Marcos Rogério, do Partido Democrático Trabalhista (PDT), de Rondônia (RO), e Bacelar, do Partido Trabalhista Nacional (PTN), da Bahia (BA). Houve substitutivo, do Deputado Diego Garcia; emenda ao substitutivo, da Deputada Erica Kokay, do Partido dos Trabalhadores (PT), do Distrito Federal (DF); e destaques, do deputado Glauber Braga, do Partido Socialismo e Liberdade (PSOL), do Rio de Janeiro (RJ). Enquanto a defesa do projeto era feita pelos deputados Marcos Feliciano, do Podemos, de São Paulo (SP), Diego Garcia, Pastor Eurico, do Partido Socialista Brasileiro (PSB), de PE, Givaldo Carimbão, do Partido Republicano da Ordem Social (PROS), de Alagoas (AL), Flavinho, do PSB-SP, e Ezequiel Teixeira, do Partido Social Democrático (PSD), do RJ, a oposição era feita por Jean Willys (PSOL-RJ), Erika Kokay e Glauber Braga.

Esse projeto foi aprovado na Comissão Especial da Câmara dos Deputados, em outubro de 2015, e seguiria para o Senado, mas foi obstruído devido aos recursos da oposição, cujas emendas visavam incluir na definição de família dada pelo estatuto aquelas formadas por pessoas do mesmo sexo, cuja união civil fora reconhecida como legal pelo Supremo Tribunal 
Federal (STF), em 2011, seguida de uma Resolução do Conselho Nacional de Justiça (CNJ), de 2013, que obrigou cartórios brasileiros a celebrarem o casamento civil entre pessoas do mesmo sexo, além de outras configurações familiares, que não incluem os pais e seus descendentes.

Esse PL foi elaborado com o propósito de definir políticas públicas voltadas para as famílias brasileiras, em diversos campos de atuação, incluindo o da saúde e educação. Ele retira diversas configurações familiares da sua abrangência, ao reconhecer como legítimas apenas as famílias compostas por casais heterossexuais ou por um desses e seus descendentes, e nega os direitos civis familiares à população LGBTQIA+, que formem um núcleo familiar, como os direitos a adoção, ao pagamento de pensão, etc. Nesse sentido, esse conceito de família apresenta regularidades com as proposições filosóficas cristãs analisadas por Foucault (2019), que concebem a existência de uma finalidade no casamento que é a procriação e também uma forma natural de relação (entre pessoas de sexos opostos) e uma forma contranatura (entre pessoas do mesmo sexo).

A Constituição Federal de 1988, em seu artigo 226, já apresenta esse conceito de família e a elege como a base da sociedade e gozadora de especial proteção do estado. O PL reforça essa visão tradicional e patriarcal, pois é fruto de um movimento conservador que tenta engessar as dinâmicas culturais. Além disso, o critério da descendência adotado para legitimar a configuração familiar elide outras formas de estabelecimento de vínculos afetivos. Assim como a inexistência de progenitura não basta para desfazer casamentos (FOUCAULT, 2019), sua existência não deveria ser critério para legitimar uniões civis.

Esse PL também trata de direitos à saúde, educação, política, economia, cultura e meio ambiente, que estariam restritos à configuração familiar legalmente reconhecida, contrariando as leis que vedam discriminação na consecução desses direitos. No campo da educação, esse projeto trata da inclusão, como componente curricular obrigatório, da disciplina "Educação para família" (artigo 10), para difundir saberes conservadores.

A justificativa da necessidade de um Estatuto da Família, dada pelo autor do PL, alega haver diversas situações enfrentadas pela família na contemporaneidade, como apresentado na introdução, que incluem o uso exagerado de drogas, a violência doméstica, a gravidez na adolescência e desconstrução do conceito de família. Esse enunciado se assemelha à requisição de uma letre de cachét (FOUCAULT, 2002), ao relacionar drogas, sexo, violência doméstica e amplitude dos arranjos familiares à fonte de problemas sociais. Conclama-se o disciplinamento das ações dos sujeitos, retirando-lhes suas liberdades para aplacar as mudanças na sociedade.

Por isso, os opositores do PL 6.583/2013 propuseram o PL 3.369/2015, que cria o Estatuto das Famílias do Século XXI, de autoria do deputado Orlando Silva (PT-SP), prevendo 
princípios para a atuação do poder público em matérias familiares. $\mathrm{O}$ seu primeiro relator foi o ex-deputado Federal Jean Willys (PSOL-RJ), substituído na relatoria por Janete Capiberibe (PSB-AP). Ainda em 2015, ele teve uma emenda do Deputado Diego Garcia, mas foi arquivado, após questionamentos dos deputados da oposição.

Retomado em 2019, a relatoria ficou a cargo do Deputado Federal Túlio Gadêlha (PDTPE). As discussões desse projeto na Comissão de Direitos Humanos e Minorias da Câmara dos Deputados foram alvo de polêmicas nas redes sociais, encabeçadas por Deputados do Partido Social Liberal (PSL), que afirmaram que o PL incentivava o incesto, a poligamia e a pedofilia. Essa discussão ocorreu em uma nova conjuntura, após a eleição de Jair Bolsonaro a presidência da república, pelo PSL, que formou maioria na Câmara dos Deputados e apresenta forte visão religiosa e conservadora. Com a pandemia causada pelo corona vírus, em 2020, esse projeto não retornou à pauta. Com só três artigos, a família é definida nesse PL nos seguintes termos:

Art. $2^{\circ}$ São reconhecidas como famílias todas as formas de união entre duas ou mais pessoas que para este fim se constituam e que se baseiem no amor, na socioafetividade, independentemente de consanguinidade, gênero, orientação sexual, nacionalidade, credo ou raça, incluindo seus filhos ou pessoas que assim sejam consideradas (PL-3.369, 2015, p. 1).

Nessa nova conjuntura política e social, essa definição repercutiu nas redes sociais. No Twitter, os Deputado Federais Carla Zambelli (PSL-SP) e Marcos Feliciano, e a Deputada Estadual Janaina Paschoal (PSL-SP) encamparam uma luta discursiva polêmica e estratégica (FOUCAULT, 2002), alegando que essa conceituação faz derivar sentidos e temas tabus. As sequências "todas as formas de união", "independentemente de consanguinidade" e "incluindo seus filhos ou pessoas que assim forem consideradas" foram enquadradas em um funcionamento da moral religiosa que, conforme Foucault (2019), desde o cristianismo primitivo condena a relação entre pessoas da mesma família.

Essa leitura é uma forma de desqualificar a relação entre pessoas do mesmo sexo, pois a nova definição estabelece jogos discursivos polêmicos (FOUCAULT, 2002) com aquela do PL-6.583/2013, que restringe formas de união familiares, limita direitos civis às pessoas ligadas por consanguinidade e só concebe como descendentes os filhos de casais heterossexuais.

Dessa maneira, esse primeiro enunciado suscitou um debate sobre a sexualidade não heterossexual no Brasil no campo político e da discussão sobre a família, encaminhando-se para o campo religioso, já que essa é a posição ocupada pelos sujeitos que o enunciam, propugnando práticas sexuais tidas como naturais e condenando aquelas que julgam serem contranatura 
(FOUCAULT, 2019). Passemos a outro enunciado, que é uma publicação do Jornal Estado do Espírito Santo ${ }^{4}$ sobre a oposição de evangélicos à vacina contra o Papiloma Vírus Humano.

Após a aprovação dessa vacina pela Organização Mundial da Saúde (OMS), ela foi lançada comercialmente no Brasil em 2006. Desde então, começaram a surgir polêmicas. Em 2009, pais declaravam acreditar que ela incentivaria as adolescentes ${ }^{5}$ a iniciarem a vida sexual cedo, já que tem ação profilática contra o vírus, causador de câncer do colo uterino e verruga genital, e são indicadas três doses antes de as meninas iniciarem a vida sexual. No entanto, o profissional de saúde não orienta a fazer tal iniciação.

Foucault (2019) nos mostra que foi estabelecida uma economia das relações sexuais que propugna a necessidade de um momento oportuno, de ocasiões que lhes legitimem. Além do casamento, essa condição precisaria ocorrer em determinada idade. No posicionamento dos sujeitos que contrariam a vacinação de meninas, temos regularidades com essa moral que se estabeleceu no âmbito da sexualidade infantil, semelhante ao que vimos no enunciado anterior.

Os dados científicos apontam que muitas meninas que iniciam a vida sexual cedo se contaminam por esse vírus, e cerca de 4000 mulheres morrem ao ano no Brasil por câncer de colo de útero, daí a urgência histórica desse dispositivo (FOUCAULT, 1999) de medicalização da sexualidade infantil como medida profilática. Essa vacina não cura quem já possui o vírus e também não serve de estimulo à precocidade sexual. Os sujeitos que assim argumentam se situam em um jogo polêmico e estratégico de discursos (FOUCAULT, 2002), mobilizando uma formulação acerca dos pecados da carne (FOUCAULT, 2019), que se estabeleceram em torno da corrupção de crianças.

Além desse argumento, havia boatos de efeitos colaterais dessa vacina, fruto do desconhecimento do seu modo de produção, que utiliza sequências do DNA dos vírus, que são proteínas inativas, sem ação infeciosa. Na história do Brasil, há registros de movimentos antivacina, como a Revolta da Vacina, de 1904, e outros movimentos contemporâneos encabeçados por líderes evangélicos e anticientificistas, como os que contrariaram as medidas de combate à disseminação do corona vírus, em 2020.

Para conscientizar da necessidade de vacinar meninas dos 11 aos 13 anos de idade, em 2014, foi lançada uma campanha televisiva, cuja data para início era o dia 10 de março desse ano, e também campanhas nas escolas para vacinação. Alguns membros da comunidade

\footnotetext{
${ }^{4}$ Um recorte dessa matéria que aqui é analisada está disponível em: https://jornalggn.com.br/saude/religiososestariam-boicotando-vacinacao-contra-virus-hpv/. Acesso em 10 jul. 2020.

${ }^{5}$ O Estatuto da Criança e do Adolescente (ECA) considera como criança a pessoa até os 12 anos de idade e adolescente aquela entre 12 e 18 anos.
} 
científica argumentavam que não haveria fortes evidências científicas da eficácia da vacina e que ela poderia aumentar a incidência de diabetes tipo 1 e outras doenças autoimunes. Tais argumentos foram rebatidos por membros da mesma comunidade científica, com evidências do saber científico, e não calcados na moral cristã.

O enunciado precedente é uma reportagem assinada por Lorrany Martins, com imagem da pastora e psicanalista Raquel Diniz Jantorno, que se enuncia como mãe de duas meninas de 10 e 3 anos de idade, as quais ela declara que não permitirá receberem a vacina quando estiverem na idade apropriada para isso; em um excerto da sua fala, ela diz que "a melhor forma de prevenir Doenças Sexualmente Transmissíveis (DSTs) é a fidelidade no casamento" (JORNAL ESTADO DO ESPÍRITO SANTO, 2014, s/p.).

Esse posicionamento discursivo (FOUCAULT, 2008) em torno da medicalização da sexualidade é reforçado por outros dois sujeitos, que são a dona de casa e evangélica Elizângela Gomes, 28, mãe de uma menina de 7 anos, e o presidente da Associação de Pastores Evangélicos da Grande Vitória, Enoque de Castro. Aquela diz que "O que previne mesmo as meninas do HPV é a relação com um só parceiro" (JORNAL ESTADO DO ESPÍRITO SANTO, 2014, s/p.). Esse, reforça a fidelidade como prevenção à doença.

Assim, a ciência da saúde e os preceitos religiosos polemizam nesse enunciado. Os sujeitos que enunciam de uma posição religiosa judaico-cristã estabelecem relações entre doença, sexo na adolescência, casamento, fidelidade e família. A religiosidade retira do saber científico da saúde a responsabilidade pela sanidade corporal e pela qualidade de vida, como ocorreu em recente manifestação de religiosos contra o abortamento feito por uma criança estuprada (UOL, 2020, online), e a atribui à vida no âmbito religioso, seguindo preceitos historicamente construídos para a vida cristã, como o casamento e a fidelidade conjugal (FOUCAULT, 2019). A fidelidade é construída no domínio do pensamento pagão e cristão, que propõe que a mulher e o homem devem ser um único corpo. O casamento seria uma reciprocidade de relações de poder.

Nesse enunciado, a fidelidade é evocada como sinônimo de uma vida saudável. Para ter saúde, a mulher precisa renunciar à liberdade sexual e entrar na ordem de um discurso que a objetiva como sujeito destinado ao casamento com um homem, e só com ele se relacionar sexualmente. A saúde é desligada do regime médico-científico e ligada a uma ordem da moral judaico-cristã na qual sexo, casamento e saúde mantêm relação.

Os sujeitos implicados nesses enunciados produzem discurso a partir de diferentes lugares enunciativos (FOUCAULT, 2008), como os de chefes de família, mães, líderes religiosos, membros da igreja, profissionais da ciência e sujeitos do cotidiano que não veem a 
ciência como relevante para a medicalização da saúde sexual infantil, visto que, para tais sujeitos, isso incita a experiência sexual precoce, deslegitimada pela lei da oportunidade e conveniência (FOUCAULT, 2019).

Esses lugares enunciativos presentes nesse enunciado também são assumidos por Levy Fidelix no terceiro enunciado que analisamos, um o vídeo do debate entre ele e Luciana Genro, transmitido pela Rede Record de televisão, no dia 28 de setembro de 2014. Transcrevemos, adiante, um recorte das falas dos dois candidatos, presentes no vídeo, cuja íntegra pode ser acessada no link especificado nas referências.

Luciana Genro: por que que as pessoas que defendem tanto a família se recusam a reconhecer como família um casal do mesmo sexo?

Levy Fidelix: jogou pesado aí agora, eh? Nessa aí você jamais deveria entrar. Economia tudo bem. Olha, minha filha, tenho 62 anos. Pelo que eu vi na vida, dois iguais não fazem filho. E digo mais, digo mais. Desculpe, mas aparelho excretor não reproduz. É feio dizer isso, mas não podemos jamais, gente... eu, que sou um pai de família, um avô..., deixar que tenhamos esses que aí estão achacando a gente do dia-a-dia, querendo escorar essa minoria à maioria do povo brasileiro (YOUTUBE, 2014, online).

A pergunta de Luciana Genro situa o casamento em um domínio discursivo dos direitos civis. Por outro lado, Levy Fidelix se situa no domínio da moral cristã e se enuncia como pertencente a um quadro familiar que ele considera como natural, legítimo e o único merecedor de reconhecimento civil. A forma como se dirige à Luciana, chamando-a de "minha filha", denota uma postura paternalista e patriarcal. Nessa arena, em que o discurso é uma arma de luta (FOUCAULT, 2002), os títulos de "pai” e "avô" são evocados como símbolos da "maioria", que toma para si o título de "povo brasileiro", contra a comunidade LGBTQIA+, enunciada como "a minoria" e adversária.

As concepções sobre o sexo evocadas no enunciado de Levy Fidelix são as de que o ato sexual visaria unicamente à reprodução e deveria ser praticado de modo "natural", por aparelhos sexuais opostos, e não por modos que seriam contranatura (FOUCAULT, 2019), com o que ele denomina de "aparelho excretor". Entretanto, em uma rápida olhada em um livro didático de ciências ou de biologia, vemos que os órgãos que formam o sistema reprodutor estão intimamente ligados à excreção. Assim, no domínio das ciências da natureza, os órgãos que realizam a excreção e a reprodução não são excludentes.

Esse enunciado mantém regularidades com tratados analisados por Foucault (2019), nos quais as ideias de uma "natura" e uma "contranatura" nas relações sexuais foram construídas no logos pagão, nos saberes da filosofia cristã e também no domínio do discurso da natureza, 
que legitimaram a prática sexual que visava à reprodução, condenando os usos dos prazeres como destemperança, ou seja, excesso sem finalidade.

Mantendo regularidades com o enunciado do jornal e o PL n ${ }^{\circ} 6.583 / 2013$, anteriormente analisados, Fidelix associa a religião a um "bom caminho familiar" e deslegitima a união homoafetiva, porque não possui como fim a procriação. Esse sujeito conclama "a maioria" a "ter coragem de enfrentar essa minoria", que é a população LGBTQIA+, recomendando que tais sujeitos sejam atendidos no plano psicológico e afetivo "bem longe da gente", ou seja, sem que tenham status de cidadãos, como propõe o PL 6.583.

Assim, a posição discursiva ocupada (FOUCAULT, 2008) por Levy Fidelix está calcada na moral religiosa cristã e na ideia de normalidade e natura, que contraria o casamento entre pessoas do mesmo sexo. Essa declaração causou indignação em muitas pessoas, que usaram as redes sociais para expressar a insatisfação com tais falas. Além disso, ações foram protocoladas no Tribunal Superior Eleitoral (TSE) por membros do PSOL, Partido Socialista dos Trabalhadores Unificado (PSTU) e da Ordem dos Advogados do Brasil (OAB), mas todas foram arquivadas, pois a arena política passou a acolher cada vez mais os discursos conservadores, que reverberam em discursos de ódio e geram múltiplas violências.

$\mathrm{Na}$ esteira da ascensão desses movimentos conservadores, ocorreu a eleição de um governo que faz da política um espaço de concretização de ideais religiosos, como pode ser visto no quarto enunciado que analisamos, um vídeo de divulgação da campanha de abstinência sexual. Em julho de 2020, foi divulgado pelo Ministério da Mulher, da Família e dos Direitos Humanos que a Ministra da pasta, Damares Alves, selecionou três (3) profissionais, das áreas do direito, saúde e educação, para construírem o "Plano Nacional de Prevenção Primária do Risco Sexual Precoce e Gravidez de Crianças e Adolescentes”. Esse programa, anunciado ainda em janeiro do mesmo ano, preconiza o retardamento da iniciação sexual de adolescentes, uma espécie de prolongamento da virgindade adolescente, e a abstinência sexual entre jovens, constituindo uma forma de continência da sexualidade (FOUCAULT, 2019).

A emergência dos temas da virgindade, da abstinência e da continência sexual como política pública governamental não é abrupta. Ocorre na esteira de uma série de acontecimentos que culminaram na assunção de lideranças políticas e religiosas conservadoras às diferentes esferas de poder e de governo no Brasil. Ao assumir o cargo, em janeiro de 2019, Damares já havia criado uma polêmica pela divulgação de um vídeo no qual diz, cercada por alguns homens, o que segue: “atenção: menino veste azul e menina veste rosa. Atenção, atenção. É uma nova era no Brasil: menino veste azul e menina veste rosa" (YOUTUBE, 2019, online), fala que situa papeis de gêneros a partir de um cromático discursivo. 
Nesse vídeo Damares está rodeada de homens enquanto fala, em um espaço de poder político tradicionalmente patriarcal. Enquanto ela sugere que "meninas vestem rosa", suas roupas são todas brancas. Ao mesmo tempo, sobressaem-se na imagem uma bandeira de Israel, demarcando o espaço judaico-cristão do seu discurso, e uma bandeira brasileira, que assinala sua ligação com um grupo que se intitula "cidadão de bem", "conservador" e "patriota", sequestrando os símbolos nacionais para uma luta na qual o discurso é a estratégia (FOUCAULT, 2002).

No nome do seu ministério, constam algumas noções (mulher, família, diretos humanos) que são objetos de intensas lutas no Brasil. Ao lançar a campanha a ser veiculada nas mídias, Damares se esforçou por refutar associações dessas noções e da sua política com uma ação moralista e fundamentalista, evocando razões de saúde pública. Essa campanha contou com a cooperação da Secretaria Nacional de Família, da Secretaria da Criança e do Adolescente e do Ministério da Saúde, esse último liderado por Luiz Henrique Mandeta à época, que disse que as ações da sua pasta consistiriam em exame pré-natal. Para ele, em vez de falar de abstinência seria necessário falar de orientações para um comportamento sexual responsável, o que se condensa no mote "espere, reflita", por acreditar que seria indevido sugerir usos de contraceptivos ou a abstinência total.

Estatisticamente, o programa é justificado pelo Ministério da Saúde pelo fato de cerca de 930 adolescentes e jovens darem à luz todos os dias no Brasil, o que equivale a 434,5 mil adolescentes que se tornam mães por ano, maior percentual entre os países da América Latina e Caribe. Ocorre que programas de abstinência sexual implantados nos Estados Unidos da América (EUA) e Unganda não se mostraram eficazes.

Essa ação de abstinência sexual complementa os termos da Lei 13.798, de 2019, que modificou o Estatuto da Criança e do Adolescente (ECA) para instituir a "Semana Nacional de Prevenção da Gravidez Precoce", comemorada em fevereiro, no início do ano letivo e, geralmente, período de carnaval, época em que ocorrem muitas relações sexuais. Nesse caso, as medidas adotadas são preventivas e educativas e não apresentam regularidades com as formas de virgindade voluntário praticada por grupos de mulheres ou a castidade elaborada pelo monaquismo (FOUCAULT, 2019), visto que o domínio discursivo que a legitima no Brasil é o da saúde, mas sempre invadido pela religião.

Entretanto, o Conselho Nacional de Saúde (CNS) recomendou que a campanha, lançada no dia 03 de fevereiro de 2020, fosse cancelada por não ver evidências científicas da eficácia da abstinência como método contraceptivo. Essa recomendação se baseou em dados do Ministério da Saúde, de 2017, que apontam redução nos registros de gravidez na adolescência 
com ações do Programa Saúde da Família e Saúde na Escola, que oferecem ações educativas e maior acesso a métodos contraceptivos, como a difusão de saberes científicos sobre saúde sexual, reprodução, desenvolvimento do corpo na adolescente, prevenção de abuso sexual, de infecções sexualmente transmissíveis, planejamento familiar e possíveis vantagens de não engravidar na adolescência.

Nos debates sobre a sexualidade no âmbito político, um dos argumentos levantados por sujeitos evangélicos é que falar sobre o sexo induz à sua prática. Por isso, tais sujeitos criticam as aulas de orientação sexual ou qualquer conteúdo escolar que trate de gênero, sexualidade e reprodução. Por outro lado, os casos diários de denúncias de estupros de crianças e adolescentes, alguns feitos por um membro da família e resultando em gravidez, mostram que há muito a se discutir sobre esses temas, em vez de realizar campanha pela virgindade.

Essa ação de abstinência sexual mantém regularidades (FOUCAULT, 2008) com as campanhas encabeçadas por movimentos religiosos com o slogan "Eu escolhi esperar", apregoando que jovens cristãos só tenham relações sexuais no casamento. Esse movimento foi fundado pelo pastor Nelson Neto Junior, que foi convidado para um seminário promovido pelo Ministério de Damares, em dezembro de 2019, na Câmara dos Deputados, sobre a prevenção da gravidez na adolescência.

Dessa maneira, é em torno desses sujeitos políticos e adeptos de religiões judaico-cristãs que a sexualidade vai se desenhando como um objeto intensamente falado, controlado, ordenado e dirigido para as finalidades da procriação no casamento, conforme Foucault (1999; 2019), sob atravessamentos discursivos da ética pagã, da moral cristã e do saber científico das ciências da natureza, domínios discursivos que se entrelaçam nos enunciados analisados, que evocam os conceitos objetos, temas e suscitam posições subjetiva aos sujeitos. Adiante, faremos as considerações finais acerca deste estudo.

\section{Conclusões}

As discussões de Foucault (2002; 2008) acerca do discurso como jogo polêmico e estratégico, de ação e reação e como uma prática que varia ao logo da história, conforme as verdades e saberes de cada época, que elabora conceitos, objetos, temas e suscita posições aos sujeitos, possibilitaram-nos analisar as lutas de sujeitos evangélicos em enunciados brasileiros que tratam da sexualidade para determinar os conceitos de família, as formas de uso do corpo, do sexo e do prazer, bem como as resistências a tais discursos.

As questões que esse autor levanta sobre o dispositivo de sexualidade, como um conjunto de elementos que se relacionam para responder a uma urgência de certo momento 
histórico (FOUCAULT, 1999), e acerca da procriação, do casamento, da virgindade, da natura, da contranatura e da fidelidade (FOUCAULT, 2019), nos possibilitaram analisar quais regularidades esses enunciados do presente mantêm com formulações dos primórdios do Cristianismo, que formularam uma moral da sexualidade.

Assim, os temas da família, do casamento, da fidelidade, do combate à homossexualidade, ao sexo e à gravidez na adolescência emergem nos discursos de sujeitos evangélicos brasileiros da atualidade para falar de sexualidade no âmbito político, se entrelaçando e se chocando com o saber científico. Ao mesmo tempo, emergem resistências a esses enunciados, configurando-se em estratégias discursivas polêmicas (FOUCAULT, 2002), que requerem formas mais democráticas de regulação da sociedade e dos corpos dos sujeitos.

\section{Referências}

“APARELHO excretor não reproduz", responde Levy Fidelix em debate. [S. 1.: s. n.], 2014. 1 vídeo (03 min e $09 \mathrm{seg}$ ). Publicado pelo canal Tvonrec4. Disponível em:

https://www.youtube.com/watch?v=5NPea2dyaEA\&t=29s. Acesso em: 10 jul. 2020.

BRASIL. Câmara dos Deputados. Projeto de Lei n ${ }^{\circ}$ 6.583, de 2013. Dispõe sobre o Estatuto da Família e dá outras providências. Disponível em:

https://www.camara.leg.br/proposicoesWeb/prop_mostrarintegra?codteor=1159761. Acesso em: 10 jul. 2020.

BRASIL. Câmara dos Deputados. Projeto de Lei no 3.369, de 2015. Institui o Estatuto das Famílias do Século XXI. Disponível em:

https://www.camara.leg.br/proposicoesWeb/prop_mostrarintegra?codteor=1402854. Acesso em: 10 jul. 2020.

BUTLER, J. Corpos que pesam: sobre os limites discursivos do sexo. In: LOURO, G. L. (Org.). O corpo educado: pedagogias da sexualidade. Belo Horizonte: Autêntica. 2000. p. $151-174$

DAMARES Alves diz que 'menino veste azul e menina veste rosa'. [S. 1.: s. n.], 2019. 1 vídeo (42 seg). Publicado pelo canal poder 360. Disponível em:

https://www.youtube.com/watch?v=q6X3-nXjmv4. Acesso em: 10 jul. 2020.

FOUCAULT, M. História da Sexualidade 1: a vontade de saber. Trad. Maria Thereza da Costa Albuquerque e J. A. Guilhon Albuquerque. 13. ed. Rio de Janeiro: Graal, 1999.

FOUCAULT, M. A verdade e as formas jurídicas. Trad. Roberto Cabral de Melo Machado e Eduardo jardim Morais. Rio de Janeiro: NAU Editora, 2002.

FOUCAULT, M. A arqueologia do saber. Trad. Luiz Felipe Baeta Neves. 7. ed. Rio de Janeiro: Forense Universitária, 2008.

FOUCAULT, M. História da Sexualidade 4: as confissões da carne. Edição estabelecida por Frédéric Gros. Tradução: Miguel Serras Pereira. Lisboa: Relógio D’água Editores, 2019. 
GOVERNO lança campanha pela abstinência sexual. [S. 1.: s. n.], 2014. 1 vídeo (42 min e 43 seg). Publicado pelo canal Poder 360. Disponível em:

https://www.youtube.com/watch?v=loFjTtxNmOw\&t=1287s. Acesso em: 10 jul. 2020.

GREGOLIN, M. do R. Foucault e Pêcheux na Análise do Discurso: diálogos e duelos. São Carlos, SP: Claraluz, 2004.

GRUPO católico faz ato em hospital de PE contra aborto de menina estuprada. UOL, Universa, violência contra a mulher, online. São Paulo, 16 ago. 2020. Disponível em: https://www.uol.com.br/universa/noticias/redacao/2020/08/16/grupo-de-catolicos-tentaimpedir-aborto-de-menina-de-10-anos.htm. Acesso em: 03 set. 2020.

MALDIDIER, D. Elementos para uma história da análise do discurso na França. In: ORLANDI, E. P. et al. (Orgs.). Gestos de Leitura: da história no discurso. 3. ed. CampinasSP: Editora da UNICAMP, 1997. p. 15-28.

MARTINS, L. Religiosas vão boicotar vacina. Jornal Estado do Espírito Santo, Vitória, fev. 2014.

ORLANDI, E. P. Análise de Discurso: princípios e procedimentos. Campinas, SP: Pontes, 2002.

\section{Sobre o autor}

Claudemir Sousa (Orcid iD: https://orcid.org/0000-0002-5318-5040)

Doutor em Linguística e Língua Portuguesa pela Universidade Estadual Paulista Júlio de Mesquita Filho (UNESP); mestre em Linguística pela Universidade Federal da Paraíba (UFPB); especialista em Linguística e Formação de Leitores pela Faculdade Futura; graduado em Letras - Língua Portuguesa e Língua Inglesa e suas respectivas literaturas pela Universidade Federal do Maranhão (UFMA). É professor do Instituto Federal de Educação, Ciência e Tecnologia do Maranhão (IFMA) - Campus Pedreiras.

Recebido em mês de 2020.

Aprovado em mês de 2020. 